\title{
Przyczynek do charakterystyki języka muzyki
}

\section{Features of the Language of Music in Brief}

\author{
Paula Trzaskawka \\ ZAKŁAD LEGILINGWISTYKI I JĘZYKÓW SPECJALISTYCZNYCH \\ INSTYTUT JEZZYKOZNAWSTWA, UNIWERSYTET IM. ADAMA MICKIEWICZA \\ AL. NIEPODLEGŁOŚCI 4, 61-874 POZNAŃ \\ paula.trzaskawka@amu.edu.pl
}

\begin{abstract}
Abstrakt
Artykuł porusza zagadnienie cech języka muzyki. Celem pracy jest omówienie wybranych cech języka muzyki takich jak polisemia, neologizmy, zapożyczenia, skróty i skrótowce, eponimy w tym toponimy i internacjonalizmy. Dodatkowo, dokonano próby zaklasyfikowania języka muzyki jako jednego z języków specjalistycznych. Język muzyki, jeżeli jest znany, może być zrozumiały prawie w każdym języku świata, ponieważ terminologia muzyczna jest $\mathrm{w}$ wielu przypadkach terminologią internacjonalną. Struktura artykułu została podzielona na dwie części teoretyczną i praktyczną (wraz z przykładami omawianych cech). Nie wszystkie cechy języka muzyki zostały wzięte pod uwagę, a ich poszerzenie powinno mieć miejsce w dalszych badaniach dotyczących omawianej tematyki.
\end{abstract}

\begin{abstract}
This article is to show the features of language of music. The presented examples were taken from Polish and some other languages, because the language of music is versatile throughout the world. The aim of the paper is to prove that the language of music is the language for special purposes and also can be understood in almost every country. The structure of the article is divided into theoretical and practical parts in which we have many explanatory examples. Not all features were described, in the nearest future such description should be broadened.
\end{abstract}

\section{Wprowadzenie}

Terminologia muzyczna nie miała jeszcze swojego miejsca w większych badaniach językoznawczych. Celem pracy jest omówienie cech języka muzyki i próba zaklasyfikowania terminologii muzycznej $\mathrm{w}$ gatunkach 
języków specjalistycznych. Terminologia, która została poddana analizie pochodzi z autentycznych oznaczeń muzycznych, które możemy znaleźć $\mathrm{w}$ nutach. Wspomniane materiały nutowe są zarazem materiałem badawczym. Metoda badawcza, która została obrana, opiera się na obserwacji empirycznej wskazanego materiału badawczego. Autorka skupia się na omówieniu takich cech, jak: polisemia, neologizmy, zapożyczenia, skróty i skrótowce, eponimy w tym toponimy i internacjonalizmy. Praca ma charakter poglądowy. Wybrano tylko niektóre cechy języka muzyki. W dalszych badaniach należałoby poszerzyć ten opis o większą ilość cech i przykładów.

\subsection{Czym jest język specjalistyczny?}

Kennedy i Bolitho (1991: 40) wyróżniają kilka rodzajów języków specjalistycznch, do największej kategorii należą LSP (Language for Specific Purposes), do nich należy LOP (Language for Occupational Purposes), czyli taki, którym posługują się poszczególne zawody i LAP (Language for Academic Purposes), do którego należą odmiany języka akademickiego. Robinson dzieli LSP na języki akademickie, profesjonalne (np. język biznesu, technologii) i zawodowe (1991: 2-4). Do zawodowych języków, można zaliczyć omawiany w artykule język muzyki. Natomiast Delisle w przekładzie Tomaszkiewicz w terminologii tłumaczenia mówi o żargonie zawodowym, technolekcie czy o języku specjalnym, czyli całości „terminów specyficznych dla pewnej działalności zawodowej, technicznej lub naukowej" (2004: 132). Ten sam autor (1999: 181) używa pojęcia języka specjalistycznego, czyli takiego, którego używa się w specjalistycznej dziedzinie, który składa się na terminologię danej dziedziny i środki wyrazowe specjalne dla tej dziedziny. Nie wyróżnia on jednak wszystkich obszarów, które mogłyby znaleźć się $\mathrm{w}$ tej kategorii. Językiem specjalistycznym posługują się prawnicy, ekonomiści, a nawet muzycy. Jest to swego rodzaju żargon, którym na co dzień posługują się użytkownicy specjalizujący się w danej dziedzinie. Aby uściślić, język specjalistyczny to skonwencjonalizowany, czyli „utworzony sztucznie język na potrzeby grupy specjalistów w danej dziedzinie bazujący na języku naturalnym” (Pytel 2004: 104), ale posiadający inny system semiotyczny. Język muzyki należy właśnie do takiej grupy języków specjalistycznych, choć niechętnie jest to przyznawane, a tłumaczenie literatury muzycznej jest traktowane pobieżnie i po macoszemu.

Biorąc pod uwagę środowisko, w którym poruszają się poszczególni specjaliści język będzie się znacząco odróżniał. I tak na przykład nie do końca zrozumiemy, o czym rozmawiają ze sobą prawnicy, a tak samo wspomniani prawnicy nie do końca zrozumieją, o czym rozmawiają muzycy. Ale tak naprawdę nie chodzi tutaj o zrozumienie dokładne i literalne. Nie chodzi tutaj o całkowitą zmianę branży i poznanie do cna każdego słowa prawniczego. Muzykowi taka wiedza nie jest potrzebna, ale gdy dotyczy to jego osobiście powinien rozumieć, co się do niego mówi i vice versa. Każda wspólnota komunikatywna (por. Zabrocki 1963) charakteryzuje się określonym zachowaniem, czynnościami i cechami dyspozycyjnymi, które 
stanowią pewną bazę określeń wewnętrznych i zewnętrznych danej wspólnoty. Zabrocki wierzył, iż teoria wspólnot komunikatywnych może stanowić swego rodzaju pomost pomiędzy językoznawstwem a historią. Ponadto, muzyków można zaklasyfikować jako odrębną wspólnotę komunikatywną, która odczuwa potrzebę porozumiewania się za pomocą „jednolitego środka komunikatywnego". Dodatkowo Matyka (2014: 2) stwierdza, iż „socjolekt nie tylko służy usprawnieniu porozumienia $\mathrm{w}$ obrębie wspólnoty komunikatywnej, lecz również sprzyja utożsamianiu się z daną zbiorowością i sygnalizowaniu przynależności, wyróżnieniu własnej grupy dla tle innych, nadaniu wagi jej uczestnikom". Dzieje się tak nie tylko dla tych grup, które usilnie tworzą hermetyczne środowisko językowe (np. prawnicy), ale też i dla tych, które tworzą nowy język, socjolekt nieświadomie.

\subsection{Język muzyki w aspekcie językoznawczym}

Język muzyki możemy podzielić na dwie kategorie. Do pierwszej należeć będzie ten ścisły, terminologiczny, natomiast do drugiej zaliczamy język ulotny, wszelkie nastroje muzyczne i wszelkie uczucia, jakie rodzi. Anna Brożek (2007: 10) uważa, że: „akustyka muzyczna, psychologia muzyki, estetykę muzyki etc. [wszelkie słownictwo związane z muzyką] należałoby uznać za subdyscypliny nie muzykologii, lecz innych dyscyplin”. Dodatkowo stwierdza, że jeśli chodzi o warstwę muzyczną (dźwięki i odbiór muzyki przez słuchacza): „mówi się niekiedy, że muzyka jest językiem. Jest jednak jasne, że muzyka nie jest jezzykiem sensu stricto: utwory muzyczne ani ich części nie służą do komunikowania się, nie stwarzają żadnych stanów rzeczy i nie wyrażają żadnych przekonań” (2007: 21). Jednakże jednocześnie autorka uważa, że istnieje kategoria języka muzykologii i terminologia muzykologiczna (2012: 126), które są zbliżone do języka naturalnego (nawet pod względem semantycznym). Cytując użyty przez autorkę przykład: „w przetworzeniu formy sonatowej występują na ogół przekształcenia wariacyjne i harmoniczne tematów i łączników" (2007: 12). Oczywiście zdanie to brzmi naturalnie dla muzyka teoretyka i muzyka praktyka, ale nie jest ono zrozumiałe dla laika, gdyż występuje w nim mnóstwo terminologii właśnie muzycznej.

Parafrazując początek angielskiego artykułu dotyczącego języka muzyki możemy stwierdzić, iż język muzyki to niepowtarzalny język, który zasługuje na miano języka specjalistycznego.

\footnotetext{
„Jeśli jesteś trenerem sportowca musisz znać wszystkie reguły gry i jej terminologię. Jeśli jesteś chemikiem musisz znać tablicę Mendelejewa jak własną kieszeń. Jeśli jesteś sędzią musisz znać prawo na wylot. $\mathrm{W}$ przypadku muzyki, ludzie uważają, że mogą z łatwością posługiwać się nią nie znając jej języka. Język muzyki powinien być nauczany, w szczególności, jeśli jesteś zainteresowany muzyką klasyczną musisz znać podstawy. Można z góry powiedzieć, że istnieje niezliczona ilość muzyków, która doprowadzi Ciebie do łez, wciąż nie odróżniając akordu As od Zis, który nie istnieje. Czego nie uda im się nadrobić z wiedzy o muzyce nadrabiają instynktem, kreatywnością, intuicją i czuciem. Oczywiście nie możemy winić
} 
takiej osoby za to. Jednakże, jakaś wiedza muzyczna jest potrzebna, jeśli zamierzasz zmierzyć się $\mathrm{z}$ tekstem muzycznym i jego przetłumaczeniem."

W momencie rozpoczęcia nauki muzyki, bardzo ważnym aspektem jest nauka czytania nut, nauka rytmów, artykulacji i dynamiki, które składają się na specjalistyczną terminologię. Można czuć muzykę w sobie, ale należy umieć czytać i pisać nuty. Jeżeli uczeń, student czy jakakolwiek inna osoba chce zagrać utwór słynnego kompozytora nie może polegać tylko na swoim zmyśle słuchu. Należy wziąć nuty do ręki i odczytać wszelkie oznaczenia, które zostały umieszczone przez kompozytora osobiście. Jeżeli ta faza zostanie wypełniona, następnie możemy dodać do tego swoją unikalną muzykalność i stworzyć piękną dla odbioru muzykę. Omówione czynności można przyrównać do przekładu intersemiotycznego, o którym mówil Jakobson. Przed interpretacją nut czy partytury odbiorca zobowiązany jest rozszyfrować znaczenie składających się na nie oznaczeń muzycznych jak i samych nut. Poprzedzająca ją percepcja komunikatów wielokodowych i interpretacja ma wymiar intersemiotyczny (Tomaszkiewicz 2005: 161-162), co zgodnie z terminologią Jakobsona (1989: 373) oznacza, że owa lektura stanowi transmutację, czyli „interpretację znaków językowych za pomocą znaków pozajęzykowych systemów znakowych" i odwrotnie. Omawiana relacja obraz-słowo, które mogą znaleźć swoje miejsce $\mathrm{w}$ legendzie (wiele utworów muzyki współczesnej posiada legendy, w których ukazany jest sposób jak wydobywać dźwięk, jak zagrać poszczególne fragmenty i thumaczone są znaki i oznaczenia w niej zawarte za pomocą słów) może zmienić charakter w przypadku różnego odbiorcy. Dla laika, niezajmującego się muzyką zawodowo i bez wykształcenia muzycznego, zwerbalizowane znaczenie użytych oznaczeń graficznych może pełnić funkcję interpretacyjną (por. Walkiewicz 2013: 82-83), która umożliwi w pewnym stopniu zrozumienie, natomiast dla muzyka specjalisty taka legenda będzie swoistym drogowskazem $\mathrm{w}$ prawidłowym wykonaniu dzieła $\mathrm{w}$ duchu zamierzenia przez kompozytora.

Kiedy mówimy o języku muzyki możemy stwierdzić, że jest to swego rodzaju żargon. Według Newmarka żargonem jest swego rodzaju utworzony język, slang, który jest niezrozumiały dla laika (1981: 131). Bardzo często podczas konwersacji muzyków, czy grania przez nich słyszymy termin „tutti”, który oznacza „wszyscy razem”, co ma powodować wspólną grę wszystkich instrumentów. Nawet jeżeli robią coś razem, niekoniecznie grając, robią to „tutti”.

W tym miejscu chciałabym zaproponować schemat, według którego określam jak klasyfikuje się terminologia muzyczna wewnątrz świata muzyki.

\footnotetext{
1 Breuner K. 2010. In theory: The language of Music. 09-05-2015. http://diymusician.cdbaby.com/2010/o1/in-theory-the-language-of-music-2/
} 


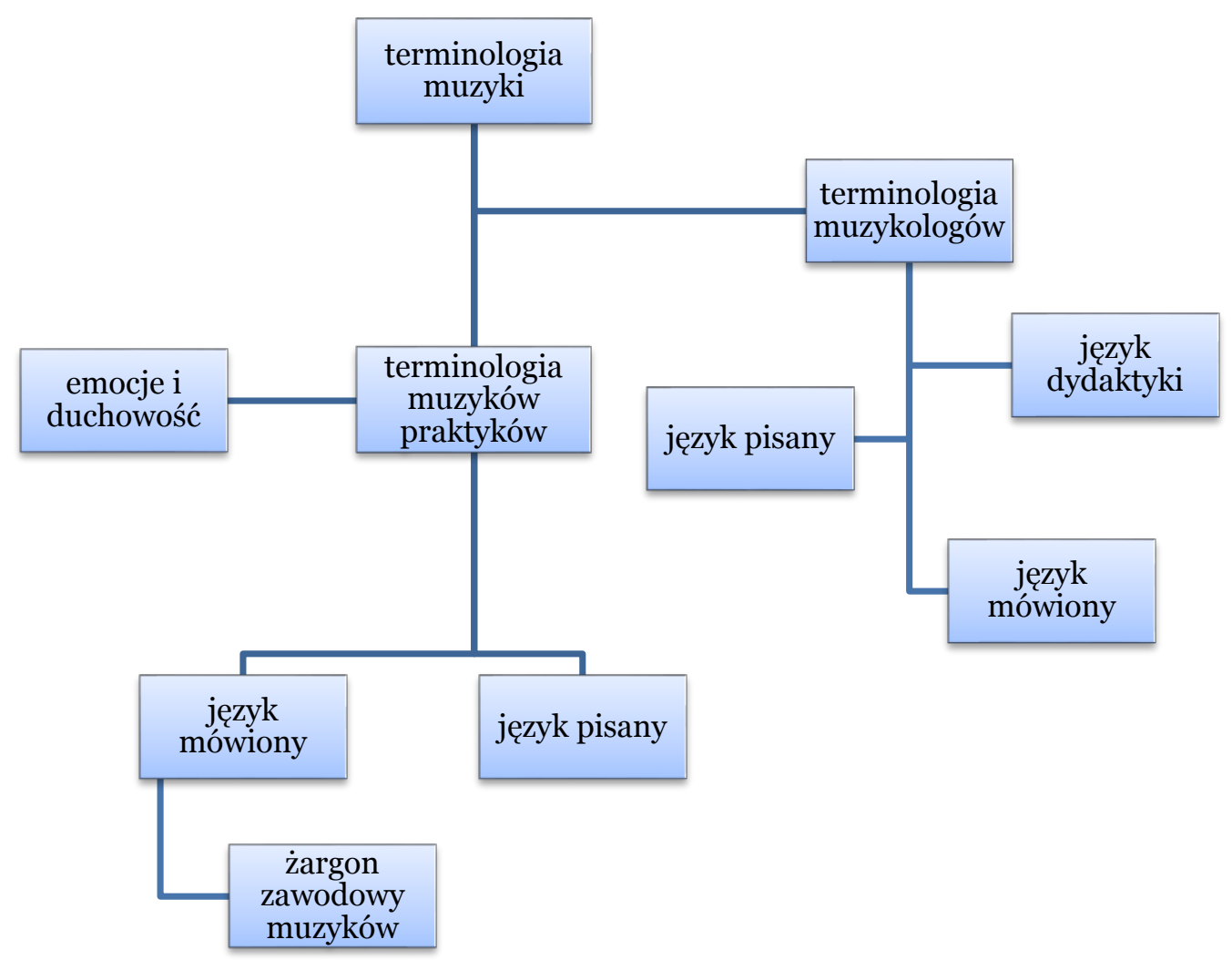

Większość terminów, które zostały zaprezentowane w niniejszym artykule zahaczają o prawie każdą kategorię przewidzianą w powyższym schemacie. Autorka skupia się, m.in. na terminologii muzyków praktyków i ich języku mówionym, na języku pisanym, używanym przez muzykologów, czy nawet wspomina o terminologii, której używa się mówiąc o muzyce jazz’owej, którą zaliczyć można do podkategorii jednego z wielu żargonów zawodowych muzyków.

\section{Wybrane cechy języka muzyki}

Poniżej zaprezentowano wybrane cechy języka muzyki, przedstawiając ich definicje, a następnie popierając je stosownymi przykładami. Zostały omówione następujące cechy: polisemia, neologizmy, zapożyczenia, skróty i skrótowce, eponimy, toponimy i internacjonalizmy.

\subsection{Polisemia}

$\mathrm{W}$ przypadku polisemii językowej mamy do czynienia $\mathrm{z}$ terminami posiadającymi różne znaczenia $\mathrm{w}$ języku ogólnym i specjalistycznym, np. w języku muzyki. Zieliński (2006: 146) o polisemii mówi tak: „polisemia polega na tym, że jeden termin ma kilka znaczeń i to znaczeń, które w jakiś sposób - nawet daleki - wiążą się ze sobą. Na przykład (...) wyraz «dom» ma siedem znaczeń. W pierwszym znaczy tyle, co «budynek przeznaczony na mieszkanie, pomieszczenie instytucji itp.», w drugim znaczy tyle co 
«mieszkanie, pomieszczenie mieszkalne, miejsce stałego zamieszkania, własny kąt». Znaczenia te mają ze sobą jakiś określony związek”. Podobne relacje możemy zaobserwować w języku muzyki.

Nie tak dawno temu musiałam swoim koleżankom i kolegom wyjaśniać, że gram koncert na klarnet na swoim recitalu dyplomowym. Wspomniane koleżanki i koledzy oczywiście z muzyką klasyczną mieli niewiele do czynienia. Nie wiedzieli, że koncert to również forma utworu muzycznego, a nie tylko wystąpienie publiczne w sali koncertowej przed publicznością.

Kolejnym przykładem polisemii będzie termin „fuga”, która jest jedną z najbardziej kunsztownych form muzycznych, oparta na ścisłej polifonii. Fugę charakteryzuje prezentacja tematu pojawiającego się w kilku głosach. Temat główny mianuje się terminem „dux”. Z łaciny termin „dux” oznacza osobę na prowadzeniu, jak i księcia, jednakże w języku muzyki jest to temat fugi. Oprócz tego fuga może stanowić część większego dzieła muzycznego jak symfonii czy koncertu (jest meronimem w stosunku do nich), gdzie pojawiają się tematy oparte na technice fugata. Oprócz fugi, jako formy muzycznej, w języku polskim występują inne znaczenia terminu fuga, np. rodzaj spoiny $\mathrm{w}$ budownictwie, bądź rodzaj zaburzenia nerwicowego.

\subsection{Neologizmy}

Neologizm to nowo utworzony, albo niedawno zapożyczony wyraz lub termin. Neologizmem będzie również nowe znaczenie istniejącego już w danym języku leksemu. Jeszcze jedną formą neologizmów są zapożyczenia (Delisle w Tomaszkiewicz 2004: 65). Natomiast jak zauważa Matulewska (2008: 59) „neologizmy stanowią bardzo duży problem tłumaczeniowy, gdyż można do nich zaliczyć, z jednej strony, nowo tworzone terminy języka docelowego nazywające byty niewystępujące do tego momentu w rzeczywistości języka prawa [można odnieść do każdej dziedziny, nie tylko prawa], które w związku z powyższym jeszcze nie zostały uwzględnione $\mathrm{w}$ słownikach bilingwalnych, a $\mathrm{z}$ drugiej - nieudane ekwiwalenty ukute dla terminów mających już swoje odpowiedniki w języku docelowym."

Do muzycznych neologizmów możemy zaliczyć, np. termin muzodajnia. Czym jest muzodajnia? To portal z najtańszą muzyką w sieci, sklep muzyczny, w którym można wykupić utwór całkowicie legalnie. Muzodajnia składa się z dwóch wyrazów, rzeczownika muzyka i czasownika dawać. Muzodajnia oznaczać będzie zatem coś co zapewnia, daję nam muzykę. Do neologizmów zaliczyć również można neosemantyzmy, czyli wykorzystywanie istniejących wyrazów w nowych sytuacjach, co prowadzi do powstawania nowych znaczeń. Takim muzycznym neosemantyzmem będzie wyraz kij używany przez klarnecistów, a oznacza on po prostu klarnet. Wyrażenie idę poćwiczyć na kiju, idę pograć na kiju oznacza grę i ćwiczenia na klarnecie. Natomiast waltorniści o swoim instrumencie mówią kibel, albo kiksofon. Kiksofon ze względu na to, że instrument ten często kiksuje (wydaje nie takie dźwięki jakie by się chciało). Kibel ze względu na 
podobny wygląd do pisuaru, ma wielką czarę. Na kontrafagot mówi się świnia (ze względu na złożoną budowę instrumentu i wielkość, jego futerał wygląda jak trumna). Czasami też skraca się wyraz kontrafagot i mówi się, że ktoś gra na kontrze. Zaś chrumkać oznacza grę na tym instrumencie. Wydobycie dźwięku w tym instrumencie określane jest tym czasownikiem właśnie ze względu na swoją specyficzną barwę. Na puzon mówi się rura bądź bambaryła, na tubę - krowa, a na saxhorn - świniak, tytka. Wiele z tych wyrazów posiada cechy zwierzęce, czasami w swoich partiach odgrywają tego typu role. Jednak nazwy te nadają muzycy, którzy w sposób dla nich żartobliwy wymyślają nowe określenia dla swoich instrumentów. W innym wypadku nowy termin powstaje samoistnie podczas prób do koncertów, gdzie każdy z instrumentalistów ma do odegrania jakąśs swoją partię, a dyrygent pragnie nacechować jakiś fragment w sposób widoczny, z należytą emfazą i czasem używa śmiesznych porównań, które bardzo szybko przyjmują się wśród muzyków i trafiają do ogólnego obiegu.

\subsubsection{Zapożyczenia}

Większość terminów muzycznych pochodzi zjęzyka włoskiego, francuskiego i niemieckiego. Ten stan uwarunkowany jest faktem, iż Włochy, Francja i Niemcy były kolebką muzyki, muzycznym centrum Europy. Większość utalentowanych kompozytorów pochodziła właśnie z terenów Niemiec, Francji, Włoch czy dzisiejszej Austrii. Dlatego tak ważnym aspektem jest znajomość terminów muzycznych właśnie z tych języków. Cały język muzyki jest potrzebny nie tylko do czytania nut, literatury muzycznej popularnonaukowej, ale też i do posługiwania się nią między muzykami czy muzykologami.

Jak stwierdza Matulewska (2008: 157), zapożyczenia mogą być bezpośrednie, np. egzotyki, czyli zapożyczenia zachowujące pisownię terminu źródłowego (np. legato, staccato), oraz zapożyczenia, które dostosowują się do pisowni języka docelowego, np. wideoklip (video clip), singiel (single). W języku muzyki najwięcej jednak jest zapożyczeń bezpośrednich. Ponadto, zapożyczenie to technika tłumaczeniowa polegająca na zachowaniu $\mathrm{w}$ tekście docelowym słowa lub wyrażenia, należącego do języka wyjściowego, ponieważ język docelowy nie dysponuje odpowiednim, zleksykalizowanym ekwiwalentem (Delisle w Tomaszkiewicz 2004: 124).

Największa liczba zapożyczeń terminów muzycznych pochodzi z języka włoskiego. W czasach dynamicznego rozwoju muzyki we Włoszech, większość muzycznych terminów i fraz została zaadaptowana $\mathrm{w}$ języku polskim. W większości wydarzenia te miały miejsce na przełomie XVI i XVII wieku. W tabeli $\mathrm{nr} 4$ przedstawiono kilka przykładów zapożyczeń z języka włoskiego do języka polskiego. 
Tabela nr 4.: Przykłady zapożyczeń z języka włoskiego do języka polskiego.

\begin{tabular}{|c|c|c|}
\hline $\begin{array}{c}\text { TERMIN } \\
\text { WŁOSKI }\end{array}$ & $\begin{array}{c}\text { TERMIN POLSKI - } \\
\text { ZAPOŻYCZONY }\end{array}$ & OBJAŚNIENIE \\
\hline A cappella & A cappella & Typ wykonania \\
\hline Allegro & Allegro & Tempo \\
\hline Balletto & Balet & Gatunek muzyczny \\
\hline Quartetto & Kwartet & $\begin{array}{r}\text { Dzieło bądź kwartet składający się } \\
\text { z czterech muzyków }\end{array}$ \\
\hline Opera & Opera & Budynek bądź gatunek muzyczny \\
\hline Sonata & Sonata & Gatunek muzyczny \\
\hline
\end{tabular}

Również z języka angielskiego pochodzi bardzo dużo zapożyczeń w naszym ojczystym języku, które nie mogą zostać wyrażone w inny sposób. Dzieje się tak dlatego, iż nie mają one swoich polskich ekwiwalentów. Większość z tych terminów pochodzi z XX wieku i dotyczy typów muzyki, np. blues, jazz, rock and roll, swing, twist, country, disco, heavy-metal, musical, pop, rock. Inne terminy zapożyczone, które są związane z muzyką to np. $D J$ (disc jockey), fan, happening, remake, hit, longplay albo playback.

\subsection{Skróty i skrótowce}

Skrótowiec to „słowo utworzone przez skrócenie wyrażenia składającego się $\mathrm{z}$ dwóch lub więcej słów. Istnieje także niewielka grupa skrótowców powstałych ze skrócenia jednego słowa" (Sierotwiński 1986: 20). Skrótowce (por. Sierotwiński 1986) należy podzielić na:

1. Literowe (złożone z pierwszych liter wyrazów skracanego wyrażenia),

2. Głoskowe (złożone, tak jak literowce, $\mathrm{z}$ pierwszych liter skracanego wyrażenia; litery skrótowca wymawiane są jednak łącznie, jako suma głosek),

3. Grupowe (składają się z grupy głosek (najczęściej pierwszych sylab), którymi rozpoczynają się słowa skracanego wyrażenia, i wymawiane są jako suma połączonych głosek (sylab). Do tej kategorii zaliczane są też skrótowce utworzone z połączenia sylab tego samego wyrazu (najczęściej pierwszej i ostatniej)),

4. Mieszane (mają niejednorodną strukturę, są kombinacjami dwóch lub nawet trzech wymienionych powyżej typów),

5. Złożeniowe (skrótowce, w skład których wchodzi cały wyraz określany i część wyrazu określającego).

Natomiast skrót to termin pochodzący od łacińskiego słowa: „brevis”, który w muzyce średniowiecza oznaczał „krótki” (długi to „longa”). Skrót, skrócenie to skrócona forma słowa bądź frazy. Zazwyczaj, ale nie jest to regułą, skrócenie składa się z litery bądź grupy liter wziętych ze słowa bądź frazy. Skróty są bardzo często używane w języku muzyki. W tabeli nr 1 przedstawiam kilka z nich: 
Paula Trzaskawka: Przyczynek do charakterystykijęzyka muzyki

Tabela nr 1.: Przykładowy wykaz skrótów i skrótowców.

\begin{tabular}{|c|c|c|c|c|}
\hline $\begin{array}{c}\text { SKRÓT W } \\
\text { LICZBIE } \\
\text { POJEDYNCZEJ }\end{array}$ & $\begin{array}{c}\text { TERMIN } \\
\text { EACINSKI } \\
\text { ROZWINIECIE } \\
\text { TERMINU) }\end{array}$ & $\begin{array}{c}\text { TERMIN } \\
\text { POLSKI }\end{array}$ & $\begin{array}{c}\text { SKRÓT W } \\
\text { LICZBIE } \\
\text { MNOGIEJ }\end{array}$ & $\begin{array}{c}\text { SŁOWO W } \\
\text { LICZBIE } \\
\text { MNOGIEJ }\end{array}$ \\
\hline op. & opus & opus & opp. & opera \\
\hline v. & volumen & $\begin{array}{c}\text { wolumin/ } \\
\text { tom }\end{array}$ & w. & volumes \\
\hline $\begin{array}{c}\text { SKRÓTOWIEC } \\
\text { W LICZBIE } \\
\text { POJEDYNCZEJ }\end{array}$ & $\begin{array}{c}\text { TERMIN } \\
\text { EACINSKI } \\
\text { TEZWINIECIE } \\
\text { TERINU) }\end{array}$ & $\begin{array}{c}\text { TERMIN } \\
\text { POLSKI }\end{array}$ & $\begin{array}{c}\text { SKRÓT W } \\
\text { LICZBIE } \\
\text { MNOGIEJ }\end{array}$ & $\begin{array}{c}\text { SŁOWO W } \\
\text { LICZBIE } \\
\text { MNOGIEJ }\end{array}$ \\
\hline MS & manu scriptum & $\begin{array}{c}\text { ręopis/ } \\
\text { manuskrypt }\end{array}$ & MSS & $\begin{array}{c}\text { manu } \\
\text { scriptus }\end{array}$ \\
\hline
\end{tabular}

W tabeli nr 2 większość zaprezentowanych skrótów i skrótowców pochodzi z muzyki orkiestrowej i kameralnej. Jednakże, każdy muzyk powinien być zaznajomiony $\mathrm{z}$ zaprezentowanym słownictwem. Większość skrótów i skrótowców dotyczy instrumentów muzycznych, głosów czy artykulacji. W tabeli poniżej zaprezentowano tylko kilka z nich ze względu na mnogość skrótów i skrótowców używanych w muzyce, partyturach, nutach, etc.

Tabela nr 2.: Przykladowe skróty i skrótowce używane w muzyce.

\begin{tabular}{|c|c|c|c|}
\hline SKRÓT & TERMIN & $\begin{array}{c}\text { POLSKIE } \\
\text { TŁUMACZENIE }\end{array}$ & KATEGORIA \\
\hline V. & violin & skrzypce & instrument \\
\hline A. & alto & alt & glos \\
\hline Ped. & pedal & pedał & $\begin{array}{c}\text { notacja } \\
\text { muzyczna }\end{array}$ \\
\hline Leg. & legato & lagato & artykulacja \\
\hline Acc. & accompaniment & akompaniament & - \\
\hline Cl & clarinet & klarnet & instrument \\
\hline Pic & piccolo & flet piccolo & instrument \\
\hline SKRÓTOWIEC & TERMIN & $\begin{array}{c}\text { POLSKIE } \\
\text { TŁUMACZENIE }\end{array}$ & KATEGORIA \\
\hline B.C. & basso continuo & $\begin{array}{c}\text { bas cyfrowany } \\
\text { motacja } \\
\text { muzyczna }\end{array}$ \\
\hline M.F. & mezzo forte & $\begin{array}{c}\text { średnio głośno/mezzo } \\
\text { forte }\end{array}$ & artykulacja \\
\hline Ppp & $\begin{array}{c}\text { pianissimo } \\
\text { possible }\end{array}$ & $\begin{array}{c}\text { możliwiejak } \\
\text { najzzipianissimo } \\
\text { possible }\end{array}$ & $\begin{array}{c}\text { oznaczenie } \\
\text { dynamiczne }\end{array}$ \\
\hline Fp & fortepiano & fortepian & instrument \\
\hline
\end{tabular}




\begin{tabular}{|c|c|c|c|}
\hline Ff & fortissimo & $\begin{array}{c}\text { bardzo } \\
\text { głośno/fortissimo }\end{array}$ & $\begin{array}{c}\text { Oznaczenie } \\
\text { dynamiczne }\end{array}$ \\
\hline
\end{tabular}

Wszystkie partytury posiadają skróty muzyczne instrumentów. Aby czytać partytury dokładnie i bez błędów (dotyczy to przede wszystkim studentów dyrygentury), należy znać wszystkie skróty. Inaczej nie jest możliwym, aby dobrze przeczytać partyturę czy zadyrygować orkiestrą.

\subsection{Eponimy}

Słowo eponim pochodzi z języka greckiego, w którym epônymos, epônumos, składa się z cząstek epi oraz ónoma. Oznaczało to dajacy imię (Rudnicka 2005: 112-116). Eponimy, inaczej - wyrazy odimienne, to ,wszystkie słowa utworzone od nazw własnych, zarówno istniejących w rzeczywistości, jak i fikcyjnych" (Sadowski 2013: 289). Eponimem jest słowo utworzone od nazwy własnej, jak i słowo, które może pochodzić od jakiejś osoby (historycznej lub fikcyjnej, człowieka, boga, herosa), rzadziej zwierzę lub przedmiot, od którego wzięła się nazwa innego terminu, rzeczy, zjawiska, miejsca, miejscowości. $\quad$ W związku z powyższym można zaproponować następujący podział na typy eponimów:

1. Od nazw własnych

a. rzeczywistych

i. imię i nazwisko (antroponimy)

b. fikcyjnych

i. imiona

ii. nazwiska

iii. nazwy

2. Od nazw budynków

3. Od nazw geograficznych (toponimy).

We współczesnym języku angielskim bardzo często spotykamy się z wyrażeniami eponimicznymi. Pojęcie to dotyczy również terminów muzycznych, przede wszystkim tytułów płyt. Zazwyczaj dzieło, które artysta utworzył nazywa tak samo jak jego pseudonim artystyczny, nazwa, bądź imię (np. piosenka „Black Sabbath” z albumu „Black Sabbath” autorstwa zespołu Black Sabbath). Bardzo wielu artystów swój pierwszy album nazywa swoim imieniem, nazwiskiem bądź pseudonimem. Powyższy przykład należeć zatem będzie do eponimów od nazw własnych, fikcyjnych.

Innym przykładem jest The Palais Garnier, znany również jako Opéra de Paris albo Opéra Garnier. Opéra Garnier to francuska opera, która pomieści 2200 widzów w Paryżu na Place de l'Opéra in Paris. Jest to pierwsza opera paryska i zarazem jedyna funkcjonująca w latach 1875-1989. Ogromny gmach budynku został zaprojektowany przez Charlesa Garniera w stylu neobarokowym. Nazwę Opéra Garnier zawdzięcza właśnie swojemu architektowi i projektantowi - Charlesowi Garnierowi. Jako, że Charles Garnier to postać rzeczywista, nazwa opery zawdzięcza swoje imię od jego 
nazwiska, dlatego będzie to eponim od nazwy własnej, nazwiska osoby rzeczywistej, czyli antroponim.

Kolejnym przykładem eponimu jest termin „klasycy wiedeńscy”. Nazwa ta została przyjęta dla trzech kompozytorów: Josepha Haydna, Wolfganga Amadeusza Mozarta oraz Ludwiga van Beethovena. Określenie to utrwaliła niemiecka muzykologia poczynając od drugiej połowy XIX wieku, traktując ich twórczość, jako apogeum europejskiej tradycji. Ich muzyka zaliczana jest stylistycznie do klasycyzmu (1750-1820), a określenie „wiedeńscy” wynika nie z faktu, iż urodzili się w Wiedniu, ale że większość swojego życia, a zwłaszcza ostatnie lata, spędzili w Wiedniu, jak również, że większość ich dzieł powstała właśnie w stolicy Austrii. Dodatkowo, należy zauważyć, że termin „klasycy wiedeńscy” został zawężony (termin uległ dodatkowemu zawężeniu) i odnosi się do tylko trzech omawianych wyżej kompozytorów. Termin „klasycy wiedeńscy” jest swego rodzaju hybrydą, gdyż łączy w sobie dwa rodzaje eponimów, eponim od nazwy („klasycy”), określający tylko daną społeczność w określonym czasie, bądź charakteryzujący się odpowiednim stylem, i od nazwy geograficznej, czyli toponim („,wiedeńscy”).

Podsumowując, w muzyce występuje wiele eponimów. Można to zaobserwować na różnych płaszczyznach, w muzyce współczesnej, architekturze, muzyce klasycznej i nazewnictwie.

\subsubsection{Toponimy}

Łacina i greka „wyprodukowały” tysiące słów i terminów, które stały się integralną częścią angielskiego języka muzyki. Z angielskiego „derived words" to nic innego jak zapożyczenia z języka łacińskiego albo z greckiego. Niektóre z tych zapożyczeń dotyczą gatunków muzycznych, co widoczne jest to przede wszystkim we współczesnym języku angielskim.

W tabeli nr 3 zaprezentowano kilka wybranych słów, które są eponimami zawierającymi toponimy (dział onomastyki zajmujący się badaniem znaczenia i pochodzenia nazw miejsc zamieszkałych, inaczej nazwami miejscowymi), które są związane z muzyką:

Tabela nr 3.: Wybrane toponimy.

\begin{tabular}{|c|l|}
\hline $\begin{array}{c}\text { DERIVED WORD } \\
\text { (SEOWO } \\
\text { ZAPOŻYCZONE, } \\
\text { TOPONIM) }\end{array}$ & \multicolumn{1}{|c|}{ POCHODZENIE } \\
\hline Britpop & Brytyjska muzyka popularna \\
\hline Chicago soul & $\begin{array}{l}\text { miasto Chicago, jako inspiracja do nazwy tego } \\
\text { rodzaju muzyki }\end{array}$ \\
\hline Dixieland jazz & $\begin{array}{l}\text { od nazwy miasta Dixie, nazwa dla południowych } \\
\text { Stanów Zjednoczonych }\end{array}$ \\
\hline Memphis soul & od nazwy miasta Memphis w stanie Tennessee \\
\hline
\end{tabular}




\begin{tabular}{|c|l|}
\hline Dunedin sound & $\begin{array}{l}\text { od nazwy miasta Dunedin w południowej części } \\
\text { Nowej Zelandii }\end{array}$ \\
\hline Urban Pasifika & od nazwy the Pacific Ocean (Ocean Spokojny) \\
\hline Philly soul & od nazwy Philadelphia w stanie Pennsylvania \\
\hline Boston (dance) & od nazwy miasta Boston \\
\hline Charleston (dance) & $\begin{array}{l}\text { od nazwy miasta Charleston w Stanach } \\
\text { Zjednoczonych }\end{array}$ \\
\hline
\end{tabular}

Wszystkie wyżej wymienione terminy nie istnieją $\mathrm{w}$ języku polskim. Znajdują one swoje zastosowanie przede wszystkim w jazzie. Polscy muzycy zapożyczają terminy wymienione w tabeli nr 3 do swojego języka. Wszystkie te pojęcia są specyficzne i nie mają swoich ekwiwalentów w języku polskim. Oprócz powyższych należy zaznaczyć, iż muzycy jazz'owi posługują się odrębnym językiem, który dla muzyka, który ma klasyczne wykształcenie, może być niezrozumiały. Część terminów jest wspólna, jest to pewna baza, w której obie grupy poruszają się swobodnie, jednakże wszelkie specjalistyczne terminy są nowe dla muzyka nie-jazz’owego, i należy je objaśnić.

\subsection{Internacjonalizmy}

Internacjonalizm to wyraz posiadający podobną formę i brzmienie w wielu różnych językach oraz wyrażający tę samą lub zbliżoną treść. Zazwyczaj wymowa i ortografia jest bardzo podobna, co powoduje, że termin czy wyraz jest rozpoznawalny w więcej niż jednym języku.

Termin „muzyka” to internacjonalizm, który w wielu innych językach wygląda następująco:

1. język angielski: music

2. język włoski/łacina: musica

3. język hiszpański: la música

4. język portugalski: música

5. język niemiecki: die Musik

6. język holenderski: muziek

7. język francuski: la musique

8. język szwedzki: musik

9. język fiński: musiikki

10. język polski/j. litewski: muzyka

11. język afrykanerski: musiek

12. język arabski: moossiqa

Ponadto, można zauważyć, że termin „muzyka” w krajach, które geograficznie graniczą ze sobą jest zbliżony. Najbardziej widoczne jest to w językach skandynawskich:

1. język szwedzki: musik

2. język fiński: musiikki

3. język duński: musik

4. język norweski: musikk. 
Internacjonalizmy pochodzą najczęściej $\mathrm{z}$ języka angielskiego, francuskiego, greckiego lub łaciny. Często niemożliwe jest określenie, który język jest bezpośrednim źródłem danego internacjonalizmu, ze względu na jego równoczesne rozpowszechnienie się na różnych obszarach (por. Nowy stownik poprawnej polszczyzny PWN i Encyklopedia języka polskiego).

Wszelkie oznaczenia temp, nazwy instrumentów, określenia dynamiczne z języka włoskiego, niemieckiego czy francuskiego mogą mieć charakter internacjonalny, czego dowodzą powyższe przykłady znajdujące się w m.in. kategoriach zapożyczeń czy skrótów. Należy jednak zauważyć, że dotyczy to przede wszystkim terminów, które pojawiają się w nutach do epoki neoklasycyzmu. Jednakże, współcześnie (po drugiej wojnie światowej) kompozytorzy coraz częściej sięgają do języka angielskiego, bądź swoich rodzimych języków.

\section{Podsumowanie}

Podsumowując, przedstawiona analiza ma charakter poglądowy i miała za zadanie zwrócić uwagę na cechy języka muzyki. Dokonano omówienia wybranych cech muzyki takich jak polisemia, neologizmy, zapożyczenia, skróty i skrótowce, eponimy $\mathrm{w}$ tym toponimy i internacjonalizmy. Wykazano, że terminologia muzyczna $\mathrm{w}$ wielu przypadkach (przede wszystkim odczytywanie partytur i oznaczeń muzycznych w nutach) jest terminologią internacjonalną i może być zrozumiała przez każdego wykształconego muzyka na świecie. Co więcej, ilość cech i przykładów, jaka została tutaj przedstawiona może stanowić podłoże do dalszych badań $\mathrm{w}$ tym zakresie.

\section{Bibliografia}

Bańczerowski, J. 2001. The linguistic legacy of Ludwik Zabrocki. W: The Ludwik Zabrocki Memorial Lecture red. Stanisław Puppel. Poznań: Adam Mickiewicz University.

Bednarczyk, A. 2008. W poszukiwaniu dominanty translatorskiej. Warszawa: Wydawnictwo Naukowe PWN.

Brożek, A. 2007. Wprowadzenie do metodologii. Warszawa: Wydawnictwo naukowe Semper.

Brożek, A. 2010. Fakty i artefakty. Warszawa: Wydawnictwo naukowe Semper.

Delisle, J. 1999. Translation terminology. Amsterdam/Philadelphia: John Benjamins Publishing Company.

Delisle J. et. al. 2004. Terminologia thumaczenia. Poznań: Wydawnictwo Naukowe UAM (tłum. Teresa Tomaszkiewicz).

Dolata-Zaród, A. 2000. O przekładzie tekstu specjalistycznego. O nauczaniu przekładu. Warszawa: TEPIS Publishing House.

Dzierżanowska, H. 1990. Ttumaczenie tekstów nieliterackich: na przykładzie języka angielskiego. Warszawa: Państwowe Wydawnictwo Naukowe.

Gołąb, Z., Heinz A., Polański K. 1970. Stownik terminologii językoznawczej. Warszawa 1968.

Habela, J. 1956. Stowniczek muzyczny. Kraków: Polskie Wydawnictwo Muzyczne. 
In theory: The language of Music. 2015-05-09.

http://diymusician.cdbaby.com/2010/o1/in-theory-the-language-of-music-2/

Jakobson, R. 1989. W poszukiwaniu istoty języka, t.1. Warszawa.

Kennedy, Ch., Bolitho R. 1991. English for Specific Purposes. Modern English Publications.

Kłos, P., Matulewska A., i Nowak-Korcz P. 2007. Problemy przekładu specjalistycznego na przykładzie tekstów $\mathrm{z}$ dziedziny prawa, biologii, biotechnologii i medycyny. W: Investigationes Linguisticae t. XV, s. 81-99.

Matulewska, A. 2008. Jakość przekładu prawniczego a cechy języka prawa. W: Język, Komunikacja, Informacja. 3/2008: s. 53-63.

Matyka, M., 2014. Socjolekt uczestników klasycznych gier fabularnych jako profesjolekt. W: Homo Ludens. Rzeszów: Uniwersytet Rzeszowski.

Newmark, P. 1981. Approaches to translation. Oxford: Pergamon Press.

Pytel, W. A. 2004. Słownictwo fachowe jako identyfikator LSP. W: Języki specjalistyczne. Vol. 4 red. Jan Lewandowski. Warszawa: Katedra Języków Specjalistycznych UW.

Rudnicka, E. 2005. Z pogranicza leksykologii i onomastyki. Przyczynek terminologiczny, W: Prace filologiczne t. L, s. 112-116.

Robinson, P. C. 1991. ESP Today: A Practitioner's Guide. New York: Prentice Hall.

Sadowski, M. 2014. Acta Erasmania. Varia. Wrocław: Wydział Prawa, Administracji i Ekonomii Uniwersytetu Wrocławskiego.

Sierotwiński, S. 1986. Stownik terminów literackich. Wrocław, Łódź: Ossolineum.

Swanwick, K. 1994. Musical Knowledge. London: Routledge.

Tomaszkiewicz, T. 2007. La traduction intersémiotique fait-elle partie de la traductologie?. W: La traduction. De la théorie à la pratique et retour red. J. Peeters, Rennes, s. 159-168.

Walkiewicz, B. 2013. Ekwiwalencja intersemiotyczna w przekładzie rysunków budowlanych. W: Rocznik Przekladoznawczy. Studia nad teoria, praktyka i dydaktyka przekładu, nr 8, s. 77-92.

Zabrocki, L. 1963. Wspólnoty komunikatywne w genezie i rozwoju języka niemieckiego. W: Prehistoria języka niemieckiego, t. I. Wrocław: Ossolineum.

Zieliński, M. 2006. Wykładnia prawa. Zasady, reguty, wskazówki. Warszawa: LexisNexis.

\section{Słowniki i encyklopedie:}

Nowy stownik poprawnej polszczyzny PWN. Warszawa: Wydawnictwo Naukowe PWN, 2002.

Encyklopedia języka polskiego. Wrocław [etc.]: Zakład Narodowy im. Ossolińskich Wydawnictwo, 1999. 